\title{
Treatability \& Biogas Production Potential of Tannery Effluent in Anaerobic Sequential Batch Rectors from One of the Tannery Found in Addis Ababa, Ethiopia
}

\author{
Alemu Bejiga Melka (Author) \\ Natural Sciences Faculty, Addis Ababa University, PO box 1177, Addis Ababa, Ethiopia \\ Eyob Mulugeta Kebede \\ College of Natural Sciences, Arba Minch University, PO box 21, Arba Minch, Ethiopia
}

\begin{abstract}
Direct discharge of tannery effluent to the surrounding water bodies affects the water quality and further causes reduction and death of aquatic fauna and flora. The effect can be minimized by treatment of tannery effluent prior to discharge to the environment. Biological treatment method is cost effective and environmentally friendly than physicochemical treatment method. The objective of this study was to develop a laboratory scale anaerobic sequence batch reactor and evaluate the treatment efficiency and biogas production potential of chrome tanning effluent at mesophilic $\left(37^{\circ} \mathrm{C} \pm 2\right)$ system. The study was conducted at five treatments (wastewater containing different concentration of chrome). The treatments (T-1 to T-5) contain chrome concentrations $\left(\mathrm{Cr}^{3+}\right) 185 \mathrm{mg} / \mathrm{l}$, $120 \mathrm{mg} / 1,14 \mathrm{mg} / 1$ and $6.85 \mathrm{mg} / 1$ for T-1, T-2, T-3, T-4, and T-5 respectively. The hydraulic retention time of all treatments was three days and five days, the organic loading rate was wide-ranging between $1.49 \mathrm{~kg} \mathrm{COD} / \mathrm{m} 3$ /day for T-1 to $1.32 \mathrm{~kg} \mathrm{COD} / \mathrm{m}^{3} /$ day forT-5 throughout the study. The removal efficiency of TS and VS of all treatments were in the range of $52-69 \%$ and $58-81 \%$, respectively. The removal efficiency of COD,BOD,TN, $\mathrm{NO}_{3}{ }^{-}, \mathrm{S}^{-2}, \mathrm{SO}_{4}{ }^{-2}, \mathrm{PO}_{4}{ }^{3-}$ and $\mathrm{Cr}^{3+}$ of all treatments were in the range of $42-62 \%, 41-71 \%, 31-43 \%, 31-49 \%, 40-$ $71 \%, 41-64 \%, 48-74 \%$ and $30-61 \%$ respectively. The maximum value of biogas at five days hydraulic retention time for (T-1 to T-5), $\left(0.0089,0.0097,0.012,0.027\right.$ and $0.034 \mathrm{~m}^{3}$ biogas $/ \mathrm{kg}$ VS respectively) with methane content $21.1 \%, 22.7 \%, 37 \%, 51.3 \%$ and $54.7 \%$ was obtained after steady stable state condition. Hence, pretreated chrome tanning effluent with $\mathrm{Cr}$ (III) of $6.85 \mathrm{mg} / \mathrm{l}$ was a potential feedstock for ASBR.
\end{abstract}

Keywords: Anaerobic sequential batch reactor, Chrome Tanning Effluent, Biogas

DOI: $10.7176 / \mathrm{JETP} / 9-1-01$

\section{INTRODUCTION}

One of the main strategic tools for the sustainable development of society all over the world is production of energy from renewable sources which is environmentally friendly. It is essential to ensure clean energy and sustainable economic development in any country. Production of renewable energy from renewable sources has many benefits that lead to environmentally friendly sustainable forms of energy (Omer, 2010). The use of fossil fuels is economically essential for electricity production, transportation, plastics and chemicals manufacturing, heating, and many other purposes. Though, the extraction and processing of fossil fuels, in addition to their use, have intense impacts on the environment and natural resources. The environmental problems with fossil fuels that control most of our attention today include acid deposition, urban air pollution, climate change and global warming including changing greenhouse effect. To protect the environment for now and future generation and also to keep up the socioeconomic, growth energy related carbon emission have to be firmly reduced. To accomplish this goal society should change the use of global energy production and consumption for example using alternative energy sources such as biomass from industrial effluents which can be used as an important alternative to fossil fuel which is unavoidable by product of industrial activities (Hussain et al., 2005). Accordingly, the challenge of energy for sustainable development requires continuous effort on the part of international organizations, national governments, the energy community, civil society, non-governmental sector (Lund \& Mathiesen, 2009).

Even if there are remarkable growth and expansion in industrial output which provided jobs and income, goods and services, and opportunities to improve the standard of living for millions of people in many countries, the environment is highly affected by solid and liquid wastes that originate from industries, such as from tanning processes (Amare Gessesse et al., 2011).

Ethiopia gives great emphasis for the transformation and industrial strategic development plan to improve export led products to join the international market in a large scale. According to EEPA, (2003) this strategy promotes capital saving and labor intensive industrial development policy using coordinated approach of supply chain management to encourage the production of value added products. Ethiopia has a major comparative advantage in the raw materials needed for the manufacturing of semi-finished and finished leather; this makes it the largest livestock production in Africa and the 10th largest in the world. Due to this the leather sector is the 
largest component of Ethiopia's export earnings. However, leather sector is highly growing in Ethiopia most of them discharge their effluent partially or without any treatment to the streams and nearby rivers (EEPA, 2003; Seyoum Leta et al., 2004). This consequence creates an environment to have a negative impact on aquatic biota public health and all biota and fauna of the surrounding. To minimize the consequence, these pollutants must be eliminated or treated before discharge to the acceptable limits through proper effluent treatment. In order to make chrome tanning effluent environmentally safe, and also to avoid its toxicity from the environment recycling or recovery methods by means of chrome precipitation with the total chromium removal is an effective way. Since cost is a major issue, economically reasonable price and alternative techniques of discharging tannery effluent should be used in order to eliminate or to at least reduce these huge environmental loads. Basically, it underlines the skills and technologies needed in planning, design, construction and management of sustainable environments which meet changing environmental, socio-cultural, technological and economic needs. These are fundamental criteria in order to provide a full understanding of sustainability implications.

One of the many economically as well as environmentally friendly suggested strategies is to design procedures that can change hazardous tannery waste products to useful biomass resources which are used for renewable energy production (WEO, 1995). For instance, the conversion of tannery effluent and other tannery waste to renewable energy can simply be done through anaerobic digestion (WEO, 1995). This method can significantly reduce hazardous organic carbon from effluent discharge to gaseous form such as methane and carbon dioxide (WEO, 1995). This method can further be used as renewable energy source and it can also be used as useful organic manure for farming purposes and make it perfect for countries like Ethiopia that are very dependent on agriculture. Consequently, changing environmental pollutants and waste materials to beneficial environmental resources such as biogas is one way of saving the planet through the use of safe renewable resources (UNEP, 1991).

Using anaerobic sequential batch reactor for treatment of tannery effluent is also used as renewable sources for energy production which has benefits that lead to environmentally friendly sustainable forms of energy (Omer, 2010). Anaerobic sequential batch reactor is a biological process which is used for industrial effluent treatment facilities for sludge degradation and stabilization, by a syndicate of microorganisms working synergistically (Joshua et al., 2008). Practically, microbial anaerobic conversion of biomass to methane is a process for effective waste treatment, biological fertilizer and sustainable energy production. Currently in Ethiopia there are about twenty six tanneries. Most of those tanneries were partially or do not treated their effluent before discharging to the nearby rivers (Seyoum Leta, 2004). This causes different problems due to high toxicity levels which accelerates water quality changes to occur. Wastewater from leather tanning process affects land surface, surface water and ground water (UNEP, 1991). The effects on surface water include rapid deterioration of physical, chemical and biological qualities (oxygen depletion and eutrophication), destruction on soil structure and acceleration of soil erosion are impacts on land surface whereas, leaching of wastewater chemicals is a principal effect on the ground water (UNEP, 1991). Direct discharge of the tannery effluent to the surrounding water bodies affects water quality and further causes reduction and death of aquatic fauna and flora (EEPA. 1993).

Different studies were conducted at laboratory scale to evaluate the biogas production potential and treatment efficiency of composite tannery wastewater and general line wastewater using two stage anaerobic sequential batch reactors. Both studies were obtained a good indication to use tannery wastewater as a feedstock for anaerobic sequential batch reactors to yield biogas energy. However, the treatability and biogas production potential of chrome line tannery effluents and the effect of chromium on quantity as well as quality of biogas production in anaerobic sequential batch reactors is not investigated. Therefore, this study was evaluated the treatability and biogas production potential of chrome line tannery effluents both before and after chrome was recovered by using anaerobic sequential batch reactors.

\subsection{MATERIALS AND METHODS}

\subsubsection{Experimental Design of ASBR}

The study was conducted at mesophilic $\left(37^{\circ} \mathrm{C} \pm 2\right)$ temperature at five different chrome concentration treatments. The treatments were labeled as $\mathrm{T}-1\left(\mathrm{Cr}^{3+} 185 \mathrm{mg} / \mathrm{l}\right)$ with full chrome content, $\mathrm{T}-2\left(\mathrm{Cr}^{3+} 120 \mathrm{mg} / \mathrm{l}\right), \mathrm{T}-3\left(\mathrm{Cr}^{3+}\right.$ $60 \mathrm{mg} / \mathrm{l}), \mathrm{T}-4\left(\mathrm{Cr}^{3+} 14 \mathrm{mg} / \mathrm{l}\right)$ and T-5 $\left(\mathrm{Cr}^{3+} 6.85 \mathrm{mg} / \mathrm{l}\right)$. Each treatment had a total liquid volume of $1.0 \mathrm{~L}$ with the same loading rates. In the experiment, each treatment was run in triplicate.

The reactors were sealed properly to avoid any leakage. The temperature of the setup was kept constant in water bath while the follow up and data collections were done regularly. The amount of biogas (volume in ml) yielded was collected and measured at three days and five days interval while biogas quality (\% methane) was measured once a week.

\subsubsection{Experimental Set Up of ASBR}

Anaerobic sequential batch reactor (ASBR) set up was arranged in the Laboratory of Center for Environmental Science; Addis Ababa University. Amber bottles of 1.0 L holding capacity was used for total treatment volume. 
The bottles were covered by rubber stopper having three hoses at the top and sealed with gas kit maker to make oxygen free environment inside the digester. Anaerobic condition was created. The three hoses on the top of the amber bottles have different purposes. The first hose was stretched up to the bottom of the solution enabling feeding of all the solution. This hose had one valve outside the digester, it was opened when the sample was feed and it was directly connected to the pump driver PD 5206 during the time of filling. The second hose was stretched up to the middle of the solution enabling decanting of the effluent. The hose had one valve outside the digester, it was opened when the sample was decanted and it were directly connected to the pump driver PD 5206 during the time of decant. After it was decanted it was disconnected from the pump driver PD 5206. While the third hose was above the solution and was used to channel the produced gas from the digester for biogas measurement during the ASBR. At the top (end) of the second hose, there was a plastic bag which was used to collect the produced biogas and it has two valves, they were close only for the period of measuring the biogas which was produced during three days and five days.

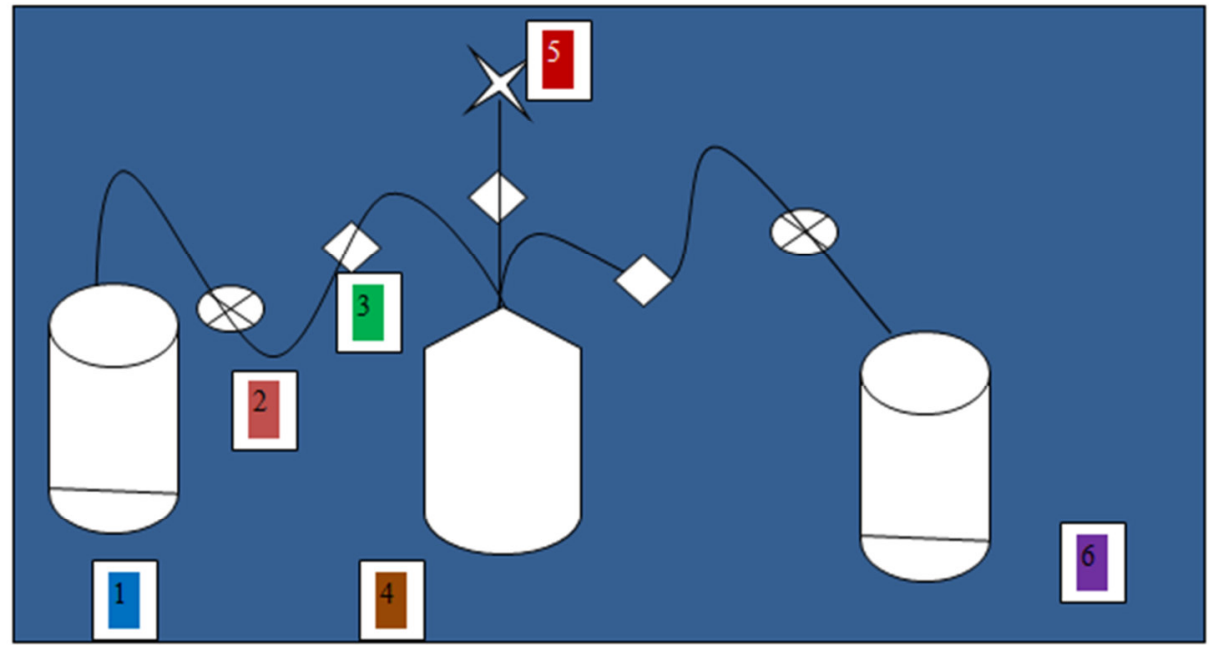

Figure 1: Schematic diagram of laboratorial single stage of ASBR (Adapted from Dugba and Zhang, 1999) where: 1. Storage tanker of the influent, 2. Pump drivers, 3. Stoppers 4. A 1L of polyethylene bottle or glass of anaerobic digestion, 5 . Bio gas collector or measuring of bio gas, 6 . Storage tanker of the effluent

The different line shows different plastic pipes which transport the influents and effluents.

\subsubsection{Operation of the ASBR}

About three months were required to accomplish the study. The startup period, the time assigns for accumulation of biomass of the ASBR was operated for one month. During this period the digester were operated in hydraulic retention time (HRT) of three days $(72 \mathrm{hr})$ cycle mode, while sixty eight hrs was given for the reaction phase and three hrs gave for settle. Anaerobic environment was made by using inoculums during startup period. After having a good biomass settling the supernatant was decanted from the upper most of the reactor for thirty min by the help of pump drivers PD 5206 with the speed of $606 \mathrm{rpm}$. Batch feeding was carried out mechanically through the top of the reactor at the beginning of the next cycle for thirty min by the same speed the substrate was decanted.

During the second phase the ASBR was operated for two months. The hydraulic retention time (HRT) was five days (120hr) cycle mode. From the total cycle time $118 \mathrm{hrs}$ was given for the reaction period, $1 \mathrm{hr}$ for settled and the remaining one hour was for fill and decants the same as in the first phase. In this phase the settling time was short due to high accumulation of biomass in the digester. The fill and decant was performed by pump drivers PD 5206 with the speed of $606 \mathrm{rpm}$ the same as the first phase. The same as to the first phase thirty min by the same speed the substrate was decanted.

\subsubsection{Determination of Quantity and Quality of Produced Biogas}

The produced biogas quantity (volume) was determined by using the syringe method when the supernatant was manually decanted and at the starting of the next cycle. The produced biogas was measured directly by measuring the volume of the gas collector bag. First, the biogas produced in the gas collector bag was disconnected from the digesters and transferred to other empty gas collector bag; this was performed by $100 \mathrm{ml}$ glass syringe. The total volume of the produced biogas was equivalent to gas transfer to the empty gas collector bag. Quality of biogas (percent of methane) was measured by biogas analyzer weakly until the gas produced was stable. The plastic bag which was filled by the biogas during measuring the volume was directly connected to the calibrated biogas analyzer and the percent of methane was displayed on the analyzer. 


\section{RESULTS AND DISCUSSION}

3.1 Treatment Performance of ASBR

3.1.1 Characteristics of the Feedstock/ Influent

\begin{tabular}{|l|l|}
\hline Parameters & Average triplicate values of chrome tanning wastewater/influent \\
\hline Moisture content $(\%)$ & $92.70 \pm 0.46$ \\
\hline $\mathrm{TS}(\%)$ & $7.30 \pm 0.46$ \\
\hline VS (\%) & $72.15 \pm 1.3$ \\
\hline Ash content (\%) & $27.85 \pm 1.3$ \\
\hline $\mathrm{OC}(\%)$ & $40.08 \pm 0.03$ \\
\hline $\mathrm{BOD}(\mathrm{mg} / \mathrm{l})$ & $910 \pm 17.3$ \\
\hline $\mathrm{TN}(\mathrm{mg} / \mathrm{l})$ & $1420 \pm 0.13$ \\
\hline $\mathrm{COD}(\mathrm{mg} / \mathrm{l})$ & $2970.15 \pm 63.50$ \\
\hline $\mathrm{PH}$ & $4.63 \pm 0.51$ \\
\hline $\mathrm{NO}_{3}{ }^{-}(\mathrm{mg} / \mathrm{l})$ & $118.21 \pm 16$ \\
\hline $\mathrm{NH}_{4}-\mathrm{N}(\mathrm{mg} / \mathrm{l})$ & $250.55 \pm 26.5$ \\
\hline $\mathrm{PO}_{4}{ }^{3-}(\mathrm{mg} / \mathrm{l})$ & $7.97 \pm 0.3$ \\
\hline $\mathrm{S}^{2-}(\mathrm{mg} / \mathrm{l})$ & $156.53 \pm 11.5$ \\
\hline $\mathrm{SO}_{4}{ }^{2-}(\mathrm{mg} / \mathrm{l})$ & $385.66 \pm 9.45$ \\
\hline $\left.\mathrm{Cr}^{\mathrm{III}}\right)(\mathrm{mg} / \mathrm{l})$ & $185.16 \pm 1.15$ \\
\hline
\end{tabular}

Table 1: Characteristics of chrome tanning wastewater prior to ASBR

3.1.2 Average Characteristics of Effluent after ASBR

The average values of the important parameters such as $\mathrm{COD}, \mathrm{BOD}, \mathrm{TN}, \mathrm{NH}_{4}-\mathrm{N}, \mathrm{NO}_{3}-\mathrm{SO}_{4}{ }^{2-}, \mathrm{S}^{2-}, \mathrm{Cr}^{3+}$ and $\mathrm{PO}_{4}{ }^{3-}$ were determined to evaluate the performance of ASBR at different organic loading rates and hydraulic retention time for each treatments and also at a controlled temperature mesophilic $\left(37^{\circ} \mathrm{C} \pm 2\right)$ system. Table 2 was shown the average triplicate values of pollutants at different hydraulic retention time for each treatment with respect to organic loading rates in mesophilic $\left(37^{\circ} \mathrm{C} \pm 2\right)$ system.

\begin{tabular}{|c|c|c|c|c|c|c|c|}
\hline \multirow[t]{2}{*}{ Parameters } & \multirow[t]{2}{*}{ Influent } & \multicolumn{6}{|c|}{$\begin{array}{l}\text { Effluent Characteristics at Different HRT \& OLR }(\mathrm{kg} / \mathrm{m} 3 / \mathrm{Day} \text { for T-1toT-5 } \\
\text { were } 1.49,1.46,1.44,1.38 \text { and } 1.34 \text { respectively) }\end{array}$} \\
\hline & & HRT & T-1 & $\mathbf{T}-2$ & $\mathbf{T}-3$ & T-4 & T-5 \\
\hline \multirow{2}{*}{$\underset{(\mathrm{mg} / \mathrm{l})}{\mathrm{SO}^{2-}}$} & \multirow{2}{*}{$\begin{array}{l}385.6 \\
\pm 9.45\end{array}$} & 3 Days & $231.4 \pm 0.7$ & $214.04 \pm 41$ & $183.9 \pm 82$ & $158.12 \pm 9$ & $146.6 \pm 6$ \\
\hline & & 5 Days & $229.01 \pm 14$ & $204.4 \pm 19$ & $177.40 \pm 42$ & $150.4 \pm 7.0$ & $138.84 \pm 4.1$ \\
\hline \multirow{2}{*}{$\mathrm{PO}_{(\mathrm{mg} / \mathrm{l})}{ }^{3-}$} & \multirow{2}{*}{$\begin{array}{l}7.97 \\
\pm 0.3\end{array}$} & 3 Days & $4.46 \pm 0.11$ & $3.91 \pm 0.3$ & $3.14 \pm 0.4$ & $2.56 \pm 30$ & $2.31 \pm 0.2$ \\
\hline & & 5 Days & $4.14 \pm 0.71$ & $3.66 \pm 0.2$ & $2.84 \pm 0.3$ & $2.47 \pm 0.7$ & $1.07 \pm 0.6$ \\
\hline \multirow{2}{*}{$\begin{array}{l}\mathrm{Cr}^{3+} \\
(\mathrm{mg} / \mathrm{l})\end{array}$} & \multirow{2}{*}{$\begin{array}{l}185.16 \\
\pm 1.15\end{array}$} & 3 Days & $116.55 \pm 14$ & $73.2 \pm 7.5$ & $34.2 \pm 3.7$ & $7.24 \pm 1.6$ & $3.08 \pm 0.4$ \\
\hline & & 5 Days & $112.9 \pm 11.6$ & $69.6 \pm 5.1$ & $30.6 \pm 2.9$ & $6.16 \pm 0.91$ & $2.69 \pm 0.45$ \\
\hline \multirow{2}{*}{$\underset{(\mathrm{mg} / \mathrm{l})}{\mathrm{NH}_{4}-\mathrm{N}}$} & \multirow{2}{*}{$\begin{array}{l}250.55 \\
\pm 26.5\end{array}$} & 3 Days & $197.5 \pm 14$ & $190.7 \pm 9$ & $187.5 \pm 8$ & $170.6 \pm 4$ & $172.5 \pm 6$ \\
\hline & & 5 Days & $192.5 \pm 11$ & $185.6 \pm 7$ & $182.5 \pm 5$ & $170.9 \pm 13$ & $165.8 \pm 9.7$ \\
\hline \multirow{2}{*}{$\begin{array}{l}\mathrm{S}^{2-} \\
(\mathrm{mg} / \mathrm{l})\end{array}$} & \multirow{2}{*}{$\begin{array}{l}156.53 \\
\pm 11\end{array}$} & 3 Days & $95.94 \pm 11$ & $88.92 \pm 7$ & $74.8 \pm 5$ & $63.65 \pm 6$ & $53.04 \pm 4$ \\
\hline & & 5 Days & $93.60 \pm 9.1$ & $79.56 \pm 6$ & $63.96 \pm 7$ & $51.48 \pm 4$ & $45.24 \pm 2$ \\
\hline \multirow[t]{2}{*}{$\mathrm{TN}^{(\mathrm{mg} / \mathrm{l})}$} & \multirow{2}{*}{$\begin{array}{l}1420 \\
\pm 0.13\end{array}$} & 3 Days & $981 \pm 19.6$ & $921 \pm 16.3$ & $882 \pm 9.3$ & $851 \pm 6.2$ & $824 \pm 3.3$ \\
\hline & & 5 Days & $952 \pm 11.8$ & $910 \pm 7.5$ & $874 \pm 6.4$ & $833 \pm 4.1$ & $810 \pm 1.9$ \\
\hline \multirow{2}{*}{$\underset{(\mathrm{mg} / \mathrm{l})}{\mathrm{COD}}$} & \multirow{2}{*}{$\begin{array}{l}2970.5 \\
\pm 163.5\end{array}$} & 3 Days & $1712.6 \pm 96$ & $1619.5 \pm 78.4$ & $1440.3 \pm 61$ & $1219 \pm 57$ & $1017.2 \pm 16$ \\
\hline & & 5 Days & $1710.14 \pm 76$ & $1589.6 \pm 41$ & $1317.9 \pm 23$ & $1219.4 \pm 9$ & $987.4 \pm 9.4$ \\
\hline \multirow{2}{*}{$\underset{(\mathrm{mg} / \mathrm{l})}{\mathrm{BOD}}$} & \multirow[t]{2}{*}{$910 \pm 17$} & 3 Days & $536.9 \pm 14.8$ & $509 \pm 9.7$ & $499.95 \pm 11$ & $385.4 \pm 7.5$ & $284 \pm 6.6$ \\
\hline & & 5 Days & $531.58 \pm 13.0$ & $490.86 \pm 7.8$ & $481.77 \pm 8$ & $341.64 \pm 4$ & $249.69 \pm 5$ \\
\hline
\end{tabular}

Table 2: Influent and effluent characteristics in mesophilic $\left(37^{0} \mathrm{C}\right)$ system at different $\mathrm{HRT}$ for each treatment before and after ASBR:

As it was seen from Table 2 the average values of the parameters COD, BOD, SO42-, $\mathrm{PO}_{4}{ }^{3-}, \mathrm{Cr}^{3+}, \mathrm{S}^{2-}, \mathrm{TN}$, $\mathrm{NH}_{4}-\mathrm{N}$ and $\mathrm{NO}_{3}{ }^{-}$retained after ASBR for T-1 at organic loading rates of $1.49 \mathrm{~kg} / \mathrm{m} 3 /$ Day and in the retention time of three days was measured the least reduction, the obtained value were $1712.6 \pm 96.4,536.9 \pm 14.8,231.39$ $\pm 0.7,4.46 \pm 0.11,116.55 \pm 14,95.94 \pm 11,981 \pm 19.6,197.5 \pm 14$ and $80.24 \pm 9.3$ respectively. For T-5 during hydraulic retention time of five days at organic loading rates of $1.34 \mathrm{~kg} / \mathrm{m} 3 /$ Day, maximum reduction of the pollutants value was obtained, the average values of the parameters $\mathrm{COD}, \mathrm{BOD}, \mathrm{SO}_{4}{ }^{2-}, \mathrm{PO}_{4}{ }^{3-}, \mathrm{Cr}^{3+}, \mathrm{S}^{2-}, \mathrm{TN}$, $\mathrm{NH}_{4}-\mathrm{N}$ and $\mathrm{NO}_{3}{ }^{-}$which was measured after ASBR of treatment (T-5) were $284 \pm 6.6,987.4 \pm 9.4,2.69 \pm 0.45$, $1.07 \pm 0.62,138.84 \pm 41,45.24 \pm 1.7,810 \pm 1.9,165.8 \pm 9.7,60.18 \pm 1.3$ respectively.

The obtained result was indicated that anaerobic sequential batch reactors in mesophilic $\left(37^{\circ} \mathrm{C}\right)$ system for 
treatment $\left(\mathrm{T}-5, \mathrm{Cr}^{3+}\right.$ of $\left.6.85 \mathrm{mg} / \mathrm{l}\right)$ was achieved the maximum pollutants reduction. It was also seen that parameters such as COD and BOD was reduced from $2970.15 \pm 163.50$ and $910 \pm 17.3$ to $987.4 \pm 9.4$ and 249.69 \pm 5 respectively. This was indicated that high amount of organic materials were converted to biogas. In general anaerobic sequential batch reactor had a potential of pollutants removal for chrome tanning wastewater at the minimum level of chrome concentration $(6.85 \mathrm{mg} / \mathrm{l})$.

It was seen that the estimated values of all pollutants for treatment (T-1) in hydraulic retention time of three days and organic loading rates of $1.49 \mathrm{~kg} / \mathrm{m} 3 /$ Day were relatively high than other treatments T-2, T-3, T-4 and T5 . The minimum retained values of all pollutants were obtained at organic loading rates $1.34 \mathrm{~kg} / \mathrm{m} 3 / \mathrm{Day}$ and hydraulic retention time of five days for treatment (T-5). The highest reduction value was determined for pollutant $\left(\mathrm{PO}_{4}{ }^{3-)}\right.$, reduced from $7.97 \pm 0.3$ to $1.07 \pm 0.62$ in which $74 \%$ removal was achieved. The least reduction was measured for pollutant $\left(\mathrm{NH}_{4}-\mathrm{N}\right), 21 \%$ removal was done which was reduced from $250.55 \pm 26.5$ to 197.5 \pm 14 .

Hydraulic retention time of five days was preferable than three days cycle frequency in reduction of pollutants for each treatments. At organic loading rates of $1.34 \mathrm{~kg} / \mathrm{m} 3$ Day than organic loading rates of $1.49 \mathrm{~kg} / \mathrm{m} 3$ Day at which the pollutant removals high with the maximum reduction.

In general the treatment performance of ASBR was indicated that, obtained characterized average value for treatment T-1,T-2 andT-3 were need further pretreatment such as chrome removal and for T-4 and T-5 the treatability of chrome tanning wastewater were almost a good performance when compared with the reports of Prakash, (2013)

\subsection{Removal Efficiency of ASBR}

3.3.1 COD, BOD and TS Removal Efficiency

The COD, BOD and TS removal efficiency of ASBR for each treatment (T-1 to T-5) at different cycle time was evaluated and results were shown in Table 3 .

\begin{tabular}{|l|l|l|l|l|l|l|}
\hline \multirow{2}{*}{ Treatments } & \multicolumn{2}{|l|}{ TS Removal (\%) } & \multicolumn{2}{l|}{ BOD Removal (\%) } & \multicolumn{2}{l|}{ COD Removal (\%) } \\
\cline { 2 - 7 } & 3Days & 5Days & 3 Days & 5 Days & 3Days & 5Days \\
\hline T-1 & 36.58 & 37.26 & 40.9 & 42.1 & 42.34 & 42.41 \\
\hline T-2 & 41.42 & 38.07 & 44.0 & 46.3 & 44.5 & 45.52 \\
\hline T-3 & 45.81 & 47.80 & 45.7 & 47.8 & 50.18 & 54.41 \\
\hline T-4 & 52.44 & 54.06 & 56.2 & 61.4 & 55.91 & 57.11 \\
\hline T-5 & 61.09 & 61.86 & 67.3 & 71.4 & 62.19 & 63.29 \\
\hline
\end{tabular}

Table 3: Removal efficiency of ASBR for parameters TS, BOD and COD at different hydraulic retention time

As it was seen from (Table 3) the percentage removal efficiency of total solids for each treatment (T-1 to T5 ) of the three days retention time in average were $36.58 \%, 41.42 \%, 45.81 \%, 52.44 \%$ and $61.09 \%$ respectively. The percentage removal of five days $(120 \mathrm{hr})$ cycle time were $37.26 \%, 38.07,47.80 \%, 54.06 \%$ and $61.68 \%$ respectively. It was shown that the removal efficiency of total solids were slightly high during the retention time of five days than the retention time of three days in all treatments.

Removal efficiency of BOD for each treatment (T-1 to T-5) during three days retention time were $40.9 \%$, $44.0 \%, 45.7 \%, 56.2 \%$ and $67.3 \%$. The BOD reduction for five days retention time for all treatments $\mathrm{T}-1$ to $\mathrm{T}-5$ were $42.1 \%, 46.3 \%, 47.8 \%, 61.4 \%$ and $71.4 \%$ respectively. The minimum reduction of BOD was obtained during hydraulic retention time of three days for treatment T-1, 40.09\%. Maximum conversion of BOD was determined for treatment T-5 during five days retention time at OLR of $1.32 \mathrm{~kg} / \mathrm{m} 3 / \mathrm{Day}$.

The COD percentage removal efficiencies of ASBR for each treatment (T-1 to T-5) in three days (72hr) and five days (120hr) retention time were $42.34 \%, 44.5 \%, 50.18 \%, 55.91 \%, 62.19 \%$ and $42.41 \%, 45.52 \%, 54.41 \%$, $57.11 \%, 63.29 \%$ respectively. The COD removal efficiencies for treatment (T-1) were the least in both $72 \mathrm{hr}$ and $120 \mathrm{hr}$ cycle time $42.34 \%$ and $42.41 \%$ respectively. The highest COD reduction percentage was measured at treatment (T-5) in the retention time of $72 \mathrm{hr}, 62.19 \%$ and $63.29 \%$ for $120 \mathrm{hr}$ cycle time.

The obtained percentage value for TS, BOD and COD was indicated that the longer cycle frequency has an advantage over the shorter cycle frequency in removing total solids; the same as to the results reported by Ndegwa et al. (2008) in the treatments of swine wastewater by anaerobic sequenced batch reactor.

The high removal efficiency of TS (\%) was a very good indication of high uptake rate of the organic fraction of total solids and the effectiveness of the ASBR; it was the same to the results (63.7\% and 69.2\%) reported by Dejene Tsegaye, (2012) and Messay Emana, (2013) respectively.

There was the utilization of the organic fraction during the anaerobic sequential batch reactions, since the value of TS (\%) before digestion was relatively higher than after digestion. The TS (\%) in this study before any treatment was $7.30 \%$ while after ASBR for each treatment (T-1 to T-5) in five days retention time were $4.62 \%$, $4.51 \%, 3.90 \%, 3.36 \%$ and $2.77 \%$ respectively.

The high removal efficiencies during treatment (T-5) at five days hydraulic retention time for BOD and 
COD were a good indication of the fact that anaerobic sequential batch reactor was under proper operating conditions. It was indicated that there is a strong linear relationship between removed BOD, COD and biogas production that support the carbon converting in to gas (Agdag \& Sponza, 2005). Treatment (T-5) was an efficient in the conversion of COD to methane in the hydraulic retention time (HRT) of five days than three days.

The conversion of COD for treatment (T-5) was 0.216 of $\mathrm{CH}_{4} / \mathrm{g}$ COD removed for three days retention time and 0.231 of $\mathrm{CH} 4 / \mathrm{g}$ COD removed for five days cycle time. In case of the treatment $(\mathrm{T}-1)$ the COD conversion to $\mathrm{CH}_{4}$ were 0.052 of $\mathrm{CH}_{4} / \mathrm{g}$ of COD for $72 \mathrm{hr}$ and $0.061 \mathrm{CH}_{4} / \mathrm{g}$ COD for $120 \mathrm{hr}$ cycle frequency respectively. The removal efficiency in all case was less than the theoretical yield which is $0.351 \mathrm{of} \mathrm{CH}_{4} / \mathrm{g}$ COD removed (Khan et al., 2001) and similar result were seen in swine wastewater treatments by ASBR reactors (Ndegwa et al., 2008). The highest COD removal shows the highest biogas production, due to its maximal conversion.

\subsection{Effect of OLR and HRT on the Quality of Biogas (\%Methane)}

The quality of biogas (\%methane) during steady stable state condition of ASBR at different cycle time frequency and organic loading rates were displayed by using biogas analyzer. The obtained result was presented in Figure 2.

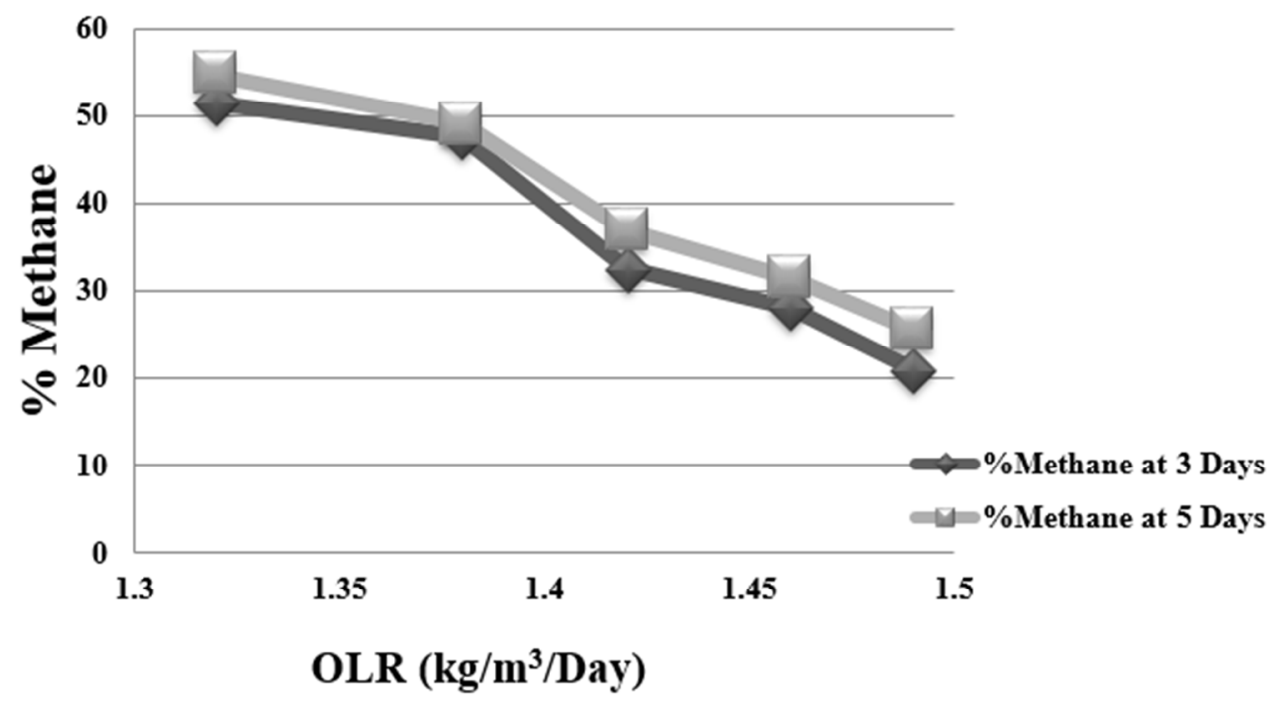

Figure 2: The effect of OLR on the quality of biogas (\%methane) at three days and five days HRT

The quality of biogas (\%methane) displayed by using biogas analyzer during three days retention time for each treatment (T-1 to $\mathrm{T}-5)$ of organic loading rates $(1.49,1.46,1.42,1.38$ and $1.32 \mathrm{~kg} \mathrm{COD} / \mathrm{m} 3 / \mathrm{Day}$ respectively) were $21.1 \pm 2.6 \%, 28.0 \pm 4.1 \%, 32.6 \pm 3.7 \%, 47.7 \pm 2.9 \%$ and $51.4 \pm 3.1 \%$ respectively. During five days hydraulic retention time the displayed value was $25.7 \pm 1.5 \%, 31.5 \pm 2.5 \%, 36.9 \pm 5 \%, 49.1 \pm 3.6 \%$ and $54.7 \pm 4.5 \%$ for treatments $\mathrm{T}-1$ to $\mathrm{T}-5$ respectively.

The qualities of biogas ( $\%$ methane) were the least for treatment $\mathrm{T}-1$ at maximum organic loading rates of $1.49 \mathrm{~kg} / \mathrm{m} 3 /$ Day during hydraulic retention time of three days, which was $21.1 \pm 2.6 \%$. At relatively minimum organic loading rates $1.32 \mathrm{~kg} / \mathrm{m} 3 /$ Day, the highest quality of biogas were obtained $54.7 \pm 4.5 \%$ of methane at steady stable state of five days retention time for treatment T-5.

The quality of gas was increased for all treatments relatively with the longer time frequency five days (120hr) retention time than three days.

The highest value of methane (\%) measured by biogas analyzer displays were shown in figure $8 \mathrm{~b}(\mathrm{CH} 4$, $54.7 \%$ and $\mathrm{CO} 2,19.3 \%$ )

\section{CONCLUSTION}

The findings of this study show that, chrome tanning effluent which contains less chrome concentration $(<6.85 \mathrm{mg} / \mathrm{l})$ after chrome was recovered were a potential feedstock for anaerobic digestion. The comparative average percentage removal of TS (36.58 - 61.09\%) for three days detention time and (37.26-61.68\%) for five cycle time was found for all treatments.

The removal efficiency of volatile solids, VS (39.48 - 66.29\%) for three days detention time and (43.17 $68.04 \%$ ) for five days cycle time was found for all treatments. Anaerobic Sequencing Batch Reactor (ASBR) had high removal efficiency of $\mathrm{COD}, \mathrm{BOD}, \mathrm{TN}, \mathrm{NO}^{3-}, \mathrm{S}^{2-}$ and $\mathrm{SO}_{4}{ }^{2-}, \mathrm{PO}_{4}{ }^{3-}$ and $\mathrm{Cr}^{3+}$ with phosphate removal efficiency of up to $74 \%$.

From the treatments under this study, treatment (T-5) produced the highest biogas of $0.034 \mathrm{~m}^{3} \mathrm{biogas} / \mathrm{kg}$ VS for five days cycle time with $57.4 \%$ (methane \%) biogas production quality. The lowest biogas produce was $0.0089 \mathrm{~m} 3$ biogas $/ \mathrm{kg}$ VS respectively with $21.1 \%$ biogas quality at treatment $(\mathrm{T}-1)$ for three days hydraulic 
retention time. The temperature was controlled at mesophlic $\left(35^{\circ} \mathrm{C}\right)$ system and the $\mathrm{pH}$ of the treatments $(\mathrm{T}-1$ to $\mathrm{T}-5)$ was in range of 5.13-6.25. Longer cycle time five days were relatively better than three days cycle time frequency for all treatments in ASBR.

\section{References}

Ağdağ, O. N., \& Sponza, D. T. (2005). Anaerobic/aerobic treatment of municipal landfill leachate in sequential two-stage up-flow anaerobic sludge blanket reactor (UASB)/completely stirred tank reactor (CSTR) systems. Process Biochemistry, 40(2), 895-902.

Amara Gessesse, Mulaa, F., Lyantagaye, S. L., Nyina-Wamwiza, L., Mattiasson, B., \& Pandey, A. (2011). Industrial enzymes for sustainable bio-economy: Large scale production and application in industry, environment, and agriculture in Eastern Africa

Dejene Tsegaye (2012). Anaerobic digestion of tannery waste for renewable energy production and waste management: a viable method to mitigate greenhouse gas emission

Dugba, P. N. and Zhang, R. (1999), Treatment of dairy wastewater with two-stage anaerobic sequencing batch reactor system - thermophilic versus mesophilic operations. Bioresource Technology, 68, p. 225-233.

EEPA,(2003). Provisional Standards for Industrial Pollution Control in Ethiopia: ESID Project, US/ETH/99/068/Ethiopia, EPA/UNIDO, Addis Ababa.

Hussain, S. M., Hess, K. L., Gearhart, J. M., Geiss, K. T., \& Schlager, J. J. (2005). In vitro toxicity of nanoparticles in BRL 3A rat liver cells. Toxicology in vitro, 19(7), 975-983.

Joshua, R., Ruihong, Z., Bryan, M. and Robert, B. (2008) Current Anaerobic Digestion Technologies Used for Treatment of Municipal Organic Solid Waste. California Integrated Waste Management Board Report, Department of Biological and Agricultural Engineering University of California, Davis

Khan, S. R., Khwaja, M. A., \& Khan, A. M. (2001). Environmental impacts and mitigation costs associated with cloth and leather exports from Pakistan. Environment and Development Economics, 6(03), 383-403.

Lund, H., \& Mathiesen, B. V. (2009). Energy system analysis of 100\% renewable energy systems-The case of Denmark in years 2030 and 2050. Energy, 34(5), 524-531.

Messay Emana, (2013). Evaluation of two Stage Anaerobic Sequence Batch Reactor (ASBR) for Production of Biogas from Composite Tannery Wastewater. (Un published Thesis).AAU. Addis Ababa.

Ndegwa, P. M., Hamilton, D. W., Lalman, J. A. and Cumba, H. J. (2008). Effects of cycle-frequency and temperature on the performance of anaerobic sequencing batch reactors (ASBRs) treating swine waste. Bioresource Technology 99, 1972-1980.

Omer, A. M. (2010). Sustainable energy development and environment. Research Journal of Environmental and Earth Sciences, 2(2), 55-75.

Prakash, N. B. (2013). Biokinetic Studies in the Treatment of Tannery Effluent. Journal of Sustainable Development, 6(6), p89.

Seyoum Leta, Fasil Assefa, Gumaelius, L., \& Dalhammar, G. (2004). Biological nitrogen and organic matter removal from tannery wastewater in pilot plant operations in Ethiopia. Applied microbiology and biotechnology, 66(3), 333-339.

UNEP (1991). Technical Guidelines on Hazardous Wastesphysico-Chemical Treatment, Biological Treatment. Basel Convention Series/SBC No: 99/007,Geneva.

UNEP (2003). ISRIC F. Soil and Terrain Database for Southern Africa (1: 2 million scale). FAO Land and Water Digital Media Series No, 25.

World Energy Outlook (WEO), (1995). International Energy Agency. OECD Publications. 2 rue Andre Pascal. Paris. France 